\title{
Assessment of Drudgery Prone Activities in Green-gram Cultivation in Bihar, India
}

\author{
Sarita Kumari $^{1 *}$, Ruplekha Borah ${ }^{2}$, Mani Bhushan ${ }^{3}$ and Aditya ${ }^{4}$
}

${ }^{1}$ College of Community \& Applied Sciences, MPUA\&T, Udaipur-313 001, Rajasthan, India

${ }^{2}$ College of Community Science, Assam Agricultural University, Jorhat-785 013, Assam, India

${ }^{3}$ Bhola Paswan Shastri Agricultural College, Purnea- 854302 Bihar, India

${ }^{4}$ Bihar Agricultural College, Sabour-813 210 Bhagalpur Bihar, India

*Corresponding author

\begin{tabular}{|c|c|}
\hline & A B S T R A C T \\
\hline & \multirow{3}{*}{$\begin{array}{l}\text { Green gram cultivation is one of the major seasonal legume crop of Bihar \& most of its } \\
\text { activities are performed by women. The present study was carried out to assess the } \\
\text { drudgery prone activities performed by farmwomen in Green Gram cultivation. The study } \\
\text { was conducted in Muzaffarpur district of Bihar in two randomly selected villages } \\
\text { Harshingpur Lautan and Shadikpur Muraul of Muraul Block. A sample size of } 80 \text { females } \\
\text { were involved in green gram cultivation in Bihar were selected by probability } \\
\text { proportionate to size method. The data were collected based on interview-cum-observation } \\
\text { method. Data was collected personally by the researcher. All the respondents were } \\
\text { interviewed with a schedule specially designed for the study. The whole process of green- } \\
\text { gram cultivation is laborious and time consuming mostly performed by farmwomen. The } \\
\text { study revealed that majority of farm women faced major drudgery during various activities } \\
\text { involved in green gram cultivation which was due to awkward postures like standing and } \\
\text { bending postures, forceful exertions causing various types of pain among the farm women. }\end{array}$} \\
\hline Article Info & \\
\hline $\begin{array}{l}\text { Accepted: } \\
\text { 17 November } 2018 \\
\text { Available Online: } \\
10 \text { December } 2018\end{array}$ & \\
\hline
\end{tabular}

\section{Introduction}

Agriculture is the backbone of the Indian economy and women play a significant role in building this economy. Agriculture is one of the drudgery prone occupations due to lack of access to improved agricultural technologies. The women's contribution to the agricultural sector is significant as they are directly involved in a majority of farm operations and play an important role in agricultural activities like inter-cultural operation, sowing, weeding, transplanting, irrigation, harvesting, plant protection, storing, winnowing etc. Besides, other farm activities performed by rural women are removing stalks, bagging picking, cleaning grains, bundling etc. Women also play an important role in conservation of soil and ecosystem. The farmwomen lead hard lives and perform heavy works in farm and homestead activities.

It is assumed, that men produce the world food, and women prepare it for the table. But, 
rural women accounts for more than half of the food produced. There is another legend that since men carry out the heavy work, when food is short they should be given the first preference. But in reality, women work greater number of hours than men and her nutritional requirements are not much different from that of men. This causes significant physical, mental exhaustion and other health problems (Agarwal et al., 2004). The main reason for all these problems are unawareness, incompatibility of the technology and attitudinal constraints.

Given the male-bias of tool-use there is a need to develop the women-friendly technologies, so that they can perform the various agricultural operations easily. The rate of these equipments is need to be cheaper so that every women can have access to it. These could include farm machines that take account of the different needs and capacities of women's bodies, catering to their typically lower mass and muscle strength, postural differences, load-bearing and lung-breathing capacity, and oxygen consumption rates. The performance of a tool or (piece of) equipment not only depends on the constructional features, but also on the workers operating it. But research in India is limited where more than two hundred million agriculture workers are women.

Sometimes women also perform pesticide spraying in some crops. This not only causing drudgery but also health hazard to women which is harmful not only to women but also to her children and family members because mostly women are involved in cooking food for family. This drudgery prone condition leads to various health problems and mechanical hazards which create physical fatigue and low productivity of women. To assess the knowledge of farm women on various technologies transferred and their acceptability by the farming community with beneficial impacts. Keeping in view, this paper aimed to assess the drudgery prone activities in cultivation of Green-gram and therefore suggesting some ergonomic recommendations on the basis of study.

The study was undertaken with the following objectives:

To find out personal and demographic profile of the female workers.

To ascertain the extent of participation of female workers in green gram cultivation.

To identify drudgery prone activities in green gram cultivation.

To suggest ergonomic recommendations for enhancing comfort of the farmwomen.

\section{Materials and Methods}

Multistage purposive cum random sampling method and probability proportionate to size method was followed for selection of state, districts, sub division, blocks, villages and respondents. Out of 37 districts of Bihar, Muzaffarpur district is selected through purposive sampling method for this study. Muzaffarpur district is divided into 16 blocks. Out of 16 blocks, one block Muraul was chosen. A list of villages of the selected block from sample was obtained from the block development office. From this list, 2 villages namely Harshingpur Lautan and Shadikpur Muraulfrom one block were selected randomly considering the following criteria-

a. The sampled villages must be nearer to the block office

b. The main occupation of farmer should be farming.

Thus, the total numbers of two villages were selected was randomly selected for the present study. With the help of village Mukhiya a list of households was prepared. Harshingpur Lautan village comprised of $280 \mathrm{HHS}$ and Shadikpur Muraul village comprised of 324 HHS. The household were selected through 
PPS method and accordingly 33 HHS from Harshingpur Lautan and 47 HHS from Shadikpur Muraul were selected. The total sample comprised of $80 \mathrm{HHS}$ and thus 80 female respondents were selected of the present study. The data were collected based on interview cum observation method. Data were collected personally by the researcher. All the respondents were interviewed with a schedule specially designed for the study. For posture analysis, still photography technique was used along with

careful observation while performing different activities by the respondents in green gram cultivation. The formula used to calculate the drudgery index is mentioned below:

\section{Drudgery index}

$$
\text { Drudgery Index }=\frac{\{\mathrm{X}+\mathrm{Y}+\mathrm{Z}\}}{3} \times 100
$$

The variables of the study and their empirical measurement is mentioned in Table 1.

\section{Method of data collection}

The data were collected based on interview cum observation method. Data were collected personally by the researcher. All the respondents were interviewed with a schedule specially designed for the study.

Care was taken only reliable and valid information were being noted down in the schedule. For posture analysis still photography technique was used along with careful observation while performing different activities by the respondents in green gram cultivation.

\section{Development of the instrument}

An interview schedule was constructed keeping in mind the different aspects. The schedule consisted of three parts:
The first part dealt with the demographic information of the respondents. Information was gathered about age, marital status, occupation, income of the family and family education.

Part 2 of the interview schedule was constructed to know the extent of participation of females involve in green gram cultivation, exertion perceived, Postures assumed in performance of various activities, musculoskeletal problem faced by farm workers. Types of body pain felt by workers after performing the activities of green gram cultivation, rest between while performing any activities in green gram cultivation was assessed.

Part 3 of the interview schedule comprises of questions related to performance frequency score, difficulty score of workers involved in green gram cultivation and time taken by workers in green gram cultivation to assess Drudgery Index.

\section{Results and Discussion}

A profile provides for cross-sectional information of a situation. Socio-economic status refers to the position of an individual with reference to various indicators of social and economic condition in a rural community. The socio-economic status has four items. The socio-economic status of selected respondent was calculated by adding the scores assigned to a category of each item.

Agriculture is the backbone of the Indian economy with over 55 per cent of Indian population depending on agriculture (Ahmad et al., 2011). In India rural people which mainly depend on agriculture and agricultural related practices. In Bihar the contribution of agriculture has remained very high as 
compared to the national average, and other states, the dependence of population on agriculture has remained consistently high. In composition of agriculture, the dominance of crops has been followed by consistent rise in contribution of livestock. The economy life of rural people of Bihar specially the scheduled caste was influenced by agricultural and allied activities and the green gram cultivation is a major part of this economy. Majority of the farm women performed the activities of green gram cultivation for their livelihood. Most of the activities are tedious, energy and time consuming, and activities were done manually by using traditional tools, caused considerable fatigue and drudgery results in low productivity. Drudgery is generally conceived as a physical mental strain, monotony hardship experienced by human beings. This may lead to body deformities and incapacitate them, thereby reducing their ability to perform work which might have indirect effect on their earning and livelihood.

The data were collected through personal interview and observation method was used. Frequency percentage, mean and Drudgery Index were used to analyse the data.

The key findings of the present study were

Data reveals that 31.25 per cent were in the age range of 36-40 years, 21.25 per cent of respondents were 26-35 years, 16.26 per cent of respondents were 15-25 years, 13.75 per cent of respondents belonged to 46-55 years and 17.5 per cent belonged to the age groups of above 55 years.

Data shows that (67.5 per cent) were illiterate, followed by 13.75 per cent of the respondents who can read and write, 9.30 per cent of the respondents were primary school level and 8.75 per cent of the respondents who were educated high school level and above.

Maximum percentages (85 per cent) of the respondents were married, 8.75 per cent of the respondents were widowed, 6.25 per cent of respondents were unmarried and 1.25 per cent of the respondents were separated.

Majority of respondents (86.25 per cent) belonged to Hindu religion and about 13.75 per cent belonged to Muslim religion.

Maximum percentage of respondents i.e. 53.75 per cent belonged to joint family followed by 37.5 per cent who belonged to nuclear family and only 8.75 per cent belonged to extended family.

Data shows that majority of respondents (61.25 per cent) belonged to Scheduled caste followed by 33.75 per cent of the respondents belonging to $\mathrm{OBC}$ and least 5 percent of the respondents belonged to General caste.

Data on monthly income of the family reveals that 61.25 per cent respondents had monthly income up toRs.6000, followed by 30 per cent of the respondents had monthly income between Rs. 6000 to Rs. 8000, 6.25 per cent of the respondents had income ranges between Rs. 8000 to Rs. 10,000 and 2.5 per cent had monthly income between Rs. 10,000 to Rs.12,000.

About 61.25 per cent were landless farmers, followed by 23.75 per cent of the respondents having land below 1 hectare, 12.5 per cent of the respondents having 1-3 hectares and 2.5 per cent of the respondents had above 3 hectares of land under cultivation. 
Table.1 Variables and their empirical measurement

Variable Empirical measurement

I. Extent of involvement

A rating scale was developed on the basis of extent of involvement categorized as follows:

\begin{tabular}{lr} 
Categories & Score \\
\hline Daily & 5 \\
Weekly & 4 \\
Monthly & 3 \\
Seasonally & 2 \\
Annually & 1
\end{tabular}

\section{Perceived exertion}

A rating scale of perceived exertion (RPE) developed by Varghese et al., (1989) was adopted to measure the perceived exertion, based on Borg's scale (Brog,1982) of subjective rating of feeling tiredness and was categorized as follows.

\section{Modified PRE scale Score}

Very light 1

Light 2

Moderately heavy 3

Heavy 4

Very heavy 5

\section{Degree of difficulty}

A rating of degree of difficulty was developed and subjective rating of feeling of difficulty was categorized as follows:

$\begin{array}{lc}\text { Categories } & \text { Score } \\ \text { Most difficult } & 5 \\ \text { Difficult } & 4 \\ \text { Sometimes difficult } & 3 \\ \text { Neutral } & 2\end{array}$

Easy 1

\section{Performance frequency score}

\section{$\underline{\text { Categories Score }}$}

Daily

Alternate day

Weekly

5

Seasonally

3

Annually

1

(

$$
5
$$

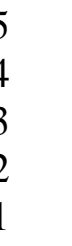
5

(
(n) 
Data shows that (68.75 per cent) were agricultural labourers, followed by 22.5 per cent respondents were cultivators, 7.5 per cent of the respondents had own business only 1.25 per cent respondents were having services.

Cent per cent of female respondents involved in all the activities like cleaning of green gram, cleaning of field, sowing and harvesting which was taken up seasonally by them.

It was observed that in 48.75 per cent households daughters participated in cleaning of green gram activity and in 51.25 per cent households, daughters in law and relatives participated. In cleaning of field, the maximum participation of husbands were seen which was about 32.5 per cent followed by other family members (28.75 per cent), and participation of daughters was 21.5 per cent and least participation was by sons (17.5 per cent). Sowing is male dominated activity as husbands (52.5 per cent) and sons (47.5 per cent) participated in this activity. In harvesting, maximum number of participation was observed from other family members (53.75 per cent) followed by daughters (41.25 per cent) and least participation was observed by sons (4 per cent).

Maximum respondents (87.5 per cent) perceived sowing and (70 per cent) cleaning of green gram as 'light' activity while 75 per cent perceived cleaning of field as 'heavy' activity, 87.5 per cent perceived harvesting activity as 'very heavy'.

Cent per cent respondents assumed squatting posture in cleaning of green gram (Activity I) and cleaning of field (Activity II). Standing posture was adopted in sowing by cent percent female workers (Activity III) and standing and bending postures was adopted in harvesting by cent percent of respondents (Activity IV).

Maximum respondents (81.25 per cent) had pain in heel frequently followed by 75 per cent of respondents having neck pain, 68.7 per cent of respondents had shoulders pain, 62.5 per cent of respondents had back pain and 58.75 per cent of respondents had pains in hands 'frequently'. The highest mean was observed in pain in heel (2.8). This may be due to the reason that activity required more static effort with standing and forward bending position along with the movement of legs to perform the activity. This was followed by neck pain (2.7), shoulders pain (2.63), back pain (2.56), pain in hand (2.55), fingers pain (2.46), Knee-Joint pain (2.45), pain in waist (2.41), pain in arms (2.21) and pain in legs (2.17).

Majority of the respondent's i.e. 91 per cent of the respondents had itching in hands and feet followed by 81.25 per cent of the respondents had tingling in the arms and finger and 71.25 per cent of the respondents had swelling in finger.

Data shows that the about 58.75 per cent of respondents took rest for 30 minutes in midmorning, 28.75 per cent and 12.5 per cent respondents took rest for 30-60 minutes and above 60 minutes in mid-morning respectively. In lunch time the maximum percentage of respondents (77.5 per cent) took rest for 30-60 minutes.

Performance frequency score was highest in harvesting activities (2.15) followed by cleaning of field (1.125), in cleaning of green gram (0.825) and minimum frequency score of women was found in sowing activities (0.5).

It was observed that as the green gram cultivation activities required more time and energy of the workers majority of respondents perceived farm activities either difficult or 'very' difficult. A difficulty score of women was highest in harvesting activities (4.87) followed by cleaning of field (4.24), in cleaning of green gram activities (2.79) and less difficulty score of women was perceived in sowing activity (2.53).

Maximum time (580 hrs/year) was spent in harvesting of green gram pod by women followed by cleaning of field activities (495 hrs/year). In cleaning of green gram activities time spent was (15.4 hrs/year) and least time was spent in sowing activities (14.33 hrs/year) by the farm women.

Data shows that in existing method the productivity of green gram pod was harvested by female Drudgery Index of the female respondents in performance of the activities of green gram cultivation was highest in harvesting (84.16), followed by cleaning of 
field (61.39), cleaning of green gram (32.34) and sowing (25.49).

Green gram picking bag was designed to enhance productivity and comfort of farm women. Productivity was obtained $600 \mathrm{gm}$ in 30 minutes by traditional basket and $1000 \mathrm{gm}$ in 30 minutes by use of picking.

Sixty per cent farm women felt 'comfortable' by using green gram picking bag followed by 21 per cent of the women found it "very comfortable' and 19 per cent of the women felt 'moderately comfortable'. As compared with existing method (Traditional basket) 60 per cent of respondents felt 'uncomfortable' and 40 per cent of respondents felt 'very uncomfortable'. The picking bag was found to be 'user friendly'.

In conclusion, it was observed from the study that drudgery in green gram cultivation was common among the respondents. Occurrence of back pain, pain in neck, pain in hand, pain in arms, finger pain and pain in heel were very much pronounced among the respondents. This study had focused on suitability of user friendly picking bag in reducing drudgery of farm women. It is envisaged that user-friendly tools for other activities in green gram cultivation will enhance comfort to the farm women. Further, the benefits of this study could be achieved through generating awareness about drudgery reducing tools and technologies among workers in green gram cultivation for improving health and productivity of farm women.

\section{Recommendations}

The impact assessment on the use of green gram picking bag should be carried out on a larger sample to study efficiency and productivity of farm women. Further studies could be conducted on development of improved tool and technologies for mitigating drudgery in the cultivation of green gram.

\section{References}

Agarwal K.N., Thomas, E.V. and Satapathy, K.K. (2004). Effect of linkages on ergonomical performance of agricultural workers of Meghalaya in pedal paddy thresher operation. Published in the proceedings of international conference on emerging technologies in agricultural and food engineering, IIT Kharagpur: 271-277.

Ahmad, J., Alam, D., and Haseen, M. S. (2011). Impact of climate change on agriculture and food security in India. International Journal of Agriculture, Environment and Biotechnology, 4(2), 129-137.

\section{How to cite this article:}

Sarita Kumari, Ruplekha Borah, Mani Bhushan and Aditya. 2018. Assessment of Drudgery Prone Activities in Green-gram cultivation in Bihar, India. Int.J.Curr.Microbiol.App.Sci. 7(12): 25362542. doi: https://doi.org/10.20546/ijcmas.2018.712.288 